\title{
A Comparison of Isozyme and Morphological Markers to Assess the Within Population Variation in Small Populations of European aspen (Populus tremula L.) in Spain
}

\author{
By U. Lopez-DE-Heredia ${ }^{1,3}$, R. Sierra-De-Grado ${ }^{1,5}$, M. D. Cristóbal ${ }^{1}$, P. Martínez-Zurimendi ${ }^{1}$, V. Pando ${ }^{2}$ and M. T. Martín ${ }^{1,4}$
}

(Received $27^{\text {th }}$ February 2004)

\begin{abstract}
Summary
European aspen (Populus tremula L.) has been traditionally thought to establish new stands by vegetative propagation through root suckers produced by very few individuals (often only one). Morphological traits and isozyme patterns were studied in five small stands in northern Spain. Both isozyme and morphological approaches showed variation within and between stands. Estimated intrapopulational variation was higher than the expected, and clusters of individuals with the same isozyme multilocus patterns within each population have been identified. In order to check to what extent morphological markers are affected by the genotypes or clones, comparisons between leaf parameters and isozyme patterns were performed by hierarchical ANOVA and tests of hypothesis were constructed from the components of variance. Leaf shape parameters show a good correlation with the isozyme multilocus patterns. On the other hand, leaf size parameters, were more influenced by environmental factors. These traits may be useful as tools for the definition of in situ conservation units in endangered European aspen stands.
\end{abstract}

Key words: Populus tremula, isozyme multilocus patterns, leaf morphology, within population variation.

\section{Introduction}

Tree species inhabiting riparian ecosystems in Southern Europe usually occur in forests along the river banks. Aspens, poplars, willows and alders are dependant on the amount of moisture in the soils, so they tend to colonise sites along rivers. These environments are frequently exposed to catastrophic events (i.e. floods) which can dramatically change the composition of these populations. Vegetative regeneration is a mechanism to counteract the effects of these events and to ensure the maintenance of the population's genetic pool.

In some taxa, asexual regeneration through vegetative propagules is even more important than sexual reproduction. The genus Populus (Salicaceae) is a good example of this strategy (BARNES, 1969; SCHIER, 1973; EINSPAHR and Winton, 1976). Populus species sprout vigorously from root or stump collars, so they can maintain stable populations within environments not suitable for the establishment of new seed originated individuals.

European aspen (Populus tremula L.) is a dioecious, windpollinated species, with a wide distribution all over Eurasia.

\footnotetext{
1) Dept. Producción Vegetal y Recursos Forestales, ETSIIAA-UVA, Avda de Madrid, 44, Campus de la Yutera, 34071 Palencia, Spain.

$\left.{ }^{2}\right)$ Dept. Estadística e Investigación Operativa, ETSIIAA-UVA, Avda de Madrid, 44, Campus de la Yutera, 34071 Palencia, Spain.

$\left.{ }^{3}\right)$ Present address: Unidad de Anatomía, Fisiología y Genética. ETSI Montes (UPM). Ciudad Universitaria s/n. 28040 Madrid, Spain.

4) Present address: Instituto Tecnológico Agrario de Castilla y León Ctra de Burgos km 119 Finca Zamadueñas, 47071 Valladolid, Spain.

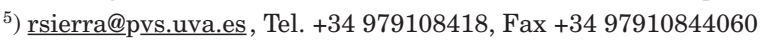

Although in northern Europe it is a pioneer species featured in the early successional stages of coniferous forests, in Spain, the southwestern limit of its distribution, it occurs in scattered patchy populations beside small streambeds in mixed broadleaved forests or in populations along rivers. These populations are composed of a small number of individuals (often less than a hundred, covering not more than 1 hectare), and they are thought to be asexually propagated by root suckers. However, little research has been devoted to the study of genetic diversity within populations, and therefore, the monoclonal character of European aspen stands is widely assumed (WoRRELL, 1995; WORRELL et al., 1999). Indeed, some large monoclonal stands have been reported (HEYBRoEK, 1984).

Nevertheless, sexual reproduction by seed is possible in European aspen. ALVAREZ et al. (2001) found remarkably high levels of seed viability in wild seeds $(66 \%$ to $99 \%$ germination in a growth chamber, and $45 \%$ to $60 \%$ under nursery conditions). In a 4-hectare aspen-dominated seminatural woodland in Scotland, isozyme analysis revealed a multiclonal structure (EASTON, 1997).

However, there is a lack of such studies in small populations of European aspen, typical in the limits of its distribution, such as Spain, Great Britain or Ireland. Indeed, these marginal populations usually are not bigger than 1 hectare, and they are traditionally managed as a single clone (WORRELL, 1995; ORIA DE RUEDA, 2003).

The assessment of variability in forest tree species has been traditionally done by means of both morphological and molecular markers. As codominant neutral markers, isozymes have been widely used to estimate the overall diversity parameters in a large number of plant taxa (HAMRICK et al., 1992) and there are many examples in genus Populus species (BERGMANN, 1987; JELINSKY and CHELIAK, 1992; LUND et al., 1992; RAJORA and DanciK, 1992; Culot, 1993; Easton, 1997; Alba and AGúNDEZ, 2000). Isozymes can be also used to genotype individuals in populations (EASTON, 1997; Montalvo et al., 1997; MAYES et al., 1998). Therefore, the genetic diversity of a population of seed originated individuals can be determined using an isozyme multilocus approach.

Most of the studies in genus Populus have been conducted on leaf traits to detect interspecific variation (BARNES and HAN, 1993; Culot, 1993). BARNes and HAN (1993) showed that Eurasian aspen taxa are highly polymorphic in their leaf morphology. However, comparisons between morphological and genotypic data are scarce and frequently do not show positive correlations.

A comparison between the two kinds of markers was performed to help in the identification of clones in small natural populations. Hence, knowledge of within-stand processes is of the utmost importance in the management of Populus tremula in marginal areas. The aim of the research reported is the development of tools for the identification of in situ conservation units. 


\section{Material and Methods}

\section{Investigated populations}

Five natural stands (Velilla, Valcobero, Tremaya, Salcedillo and Congosto) were selected from a previously developed inventory of aspen stands in Palencia, northwestern Spain (Consejería de Medio Ambiente, Junta de Castilla y León, unpublished data). The name, location (latitude and longitude), kind of stand and sex of the trees in the selected populations are briefly described in Table 1.

Table 1. - Location and characteristics of the studied populations: name, longitude, latitude, short description and sex of the trees in the population ( $\mathrm{M}=$ male, $\mathrm{F}$ = female).

\begin{tabular}{lllll} 
Population & Longitude & Latitude & Description & Sex \\
\hline Velilla & $451 \mathrm{~W}$ & $4250 \mathrm{~N}$ & Riparian forest, compact population & $\mathrm{M} / \mathrm{F}$ \\
Valcobero & $447 \mathrm{~W}$ & $4252 \mathrm{~N}$ & Several stands spread in a valley & $\mathrm{M} / \mathrm{F}$ \\
Tremaya & $428 \mathrm{~W}$ & $4259 \mathrm{~N}$ & An unique compact stand & $\mathrm{M}$ \\
Salcedillo & $416 \mathrm{~W}$ & $4257 \mathrm{~N}$ & Dispersed trees in a Quercus and Fagus forest & $\mathrm{M} / \mathrm{F}$ \\
Congosto & $438 \mathrm{~W}$ & $4243 \mathrm{~N}$ & Relict aspens in a Quercus pyrenaica stand & $\mathrm{M}$ \\
\hline
\end{tabular}

The five selected populations are representative of different stand development stages. Velilla is a young stand, mixed with Fagus sylvatica, Fraxinus sp. and Salix sp., stretching along the banks of a river. Male and female individuals have been detected and the stand is in a generally healthy condition. Valcobero is made up of several stands spread over a valley floor. Some of them are monospecific pure stands; others are mixed with Quercus petraea. Very healthy male and female individuals have been recorded. Tremaya is a young, compact and small stand that occupies a northern exposure slope. It is flanked by Fagus sylvatica and mixed with few scattered individuals and old stumps of Quercus petraea. Salcedillo is a stand in a mature stage, showing signs of poor health, with aspen individuals scattered among the mosaic of species that conforms the surrounding forest (Quercus petraea, Fagus sylvatica, Quercus robur, Betula pendula, Sorbus sp., etc.). Both female and male individuals occur. Congosto is a mature stand that is in the middle of a Quercus pyrenaica forest on the fringes of the area with suitable ecological conditions for P. tremula. There is historical evidence of a large aspen population in this area (MADOZ, 1845-1850), but all that remains now is a small stand with unhealthy senescent individuals. Only male individuals have been found.

\section{Isozyme Analysis}

A minimum of 23 and a maximum of 30 trees were sampled in each population. Individual trees were chosen according to the accessibility to the samples, largest diameters and maintaining the maximum possible distance among them, to sample the greatest variability. Twigs were collected and stored with their base immersed in water to mantain living buds. Prior to extraction, buds were steeped in water for two days. Horizontal starch gel electrophoresis was used to assay ten enzyme systems with three different buffer systems. Starch (S-4501) gels were prepared at $11.5 \%$, adding sucrose $(3.5 \%)$ to ease migration. 3 to 4 buds were ground up in $500 \mu \mathrm{l}-1 \mathrm{ml}$ of extraction buffer. The extract was absorbed onto $0.5 \times 1 \mathrm{~cm}$ Whatman 3 MM papers, which were inserted into the starch gels.

Staining procedures and buffers were modified from ALBA and AGUNDEZ (2000), with an important reduction on reactive volumes. The following systems were studied: IDH, 6PGD, GOT, LAP, ADH, SKDH, PGI, MDH, PGM and ACPH. Electrophoresis conditions, buffers and enzyme systems are described in Table 2.

The extensive literature on Populus species was used to interpret the different enzyme systems. Loci were numbered
Table 2. - Enzyme systems analyzed, buffer systems and electrophoresis conditions.

\begin{tabular}{|c|c|c|c|c|}
\hline Enzyme systems & Abbreviation & $\begin{array}{l}\text { E.C. } \\
\text { code }\end{array}$ & Buffer system & $\begin{array}{l}\text { Electrophoresis } \\
\text { conditions }\end{array}$ \\
\hline Leucineaminopeptidase & LAP & 3.4 .11 .1 & \multirow{3}{*}{$\begin{array}{c}\text { Tris-citrate-Litium } \\
\text { borate } \mathrm{pH} 8.3\end{array}$} & \multirow{3}{*}{$\begin{array}{l}\mathrm{V}=380 \mathrm{~V} \\
\mathrm{I}=75 \mathrm{~mA}\end{array}$} \\
\hline $\begin{array}{l}\text { Glutamate oxaloacetic } \\
\text { transaminase }\end{array}$ & GOT & 2.6.1.1 & & \\
\hline Alcohol dehydrogenase & $\mathrm{ADH}$ & 1.1.1.1 & & \\
\hline Shikimate dehydrogenase & SKDH & 1.1 .1 .25 & \multirow{4}{*}{$\begin{array}{c}\text { Morpholine-Citrate } \\
\text { pH } 6.7\end{array}$} & \multirow{4}{*}{$\begin{array}{l}\mathrm{V}=210 \mathrm{~V} \\
\mathrm{I}=60 \mathrm{~mA}\end{array}$} \\
\hline Isocitrate dehydrogenase & IDH & 1.1 .1 .42 & & \\
\hline $\begin{array}{l}\text { 6-Phosphogluconate } \\
\text { dehydrogenase }\end{array}$ & 6PGD & 1.1.1.44 & & \\
\hline Malate dehydrogenase & $\mathrm{MDH}$ & 1.1.1.37 & & \\
\hline Phosphoglucose isomerase & PGI & 5.3 .1 .9 & \multirow{2}{*}{$\begin{array}{c}\text { Morpholine-Citrate } \\
\text { pH } 6.7\end{array}$} & \multirow{2}{*}{$\begin{array}{l}\mathrm{V}=210 \mathrm{~V} \\
\mathrm{I}=60 \mathrm{~mA}\end{array}$} \\
\hline $\begin{array}{l}\text { Phosphoglucomutase } \\
\text { Acid phosphatase }\end{array}$ & $\begin{array}{l}\text { PGM } \\
\text { ACPH }\end{array}$ & $\begin{array}{l}2.7 .5 .1 \\
3.1 .3 .2\end{array}$ & & \\
\hline
\end{tabular}

assigning A to the locus with the fastest migrating isozyme bands, $\mathrm{B}$ to the second fastest, and so on. Allele notation followed the same procedure but using numbers instead of capital letters $(1,2,3 \ldots)$.

General diversity parameters (number of alleles $-\mathrm{N}_{\mathrm{a}}{ }^{-}$, effective number of alleles $-\mathrm{N}_{\mathrm{e}}$, percentage of polymorphic loci, observed $-\mathrm{H}_{\mathrm{o}}$ - and expected heterozygosity $-\mathrm{H}_{\mathrm{e}}$ - (NEI, 1973)) for each population were calculated with Popgene version 1.31 (YEH et al., 1999) in order to compare with previous studies at a within population level.

To assess the number of genetically different individuals, a multilocus analysis was performed obtaining distribution frequencies of the multilocus isozyme patterns for each population. We scored the absolute number of genotypes (NG) and compute the relative number of genotypes as NGr1 $=\mathrm{NG} 1 / \mathrm{Ni1}$ $(\mathrm{NGr} 1=$ relative number of genotypes in population 1 , NG1 = absolute number of genotypes in population 1, $\mathrm{Ni1}=$ number of individuals (sampled) in population 1). Discriminant power of these isozyme loci (ASPINWALL and Christian, 1992) has been estimated as $89 \%$ in a wider study in Tremaya (report in preparation). This parameter is the mean probability of two individuals showing the same isozyme pattern to have the same genotype.

\section{Morphological Analysis}

Sampling for the morphological analysis was performed following BARNES (1969). In 15 to 30 individuals per population, five fully expanded leaves per individual were sampled. Leaves were scanned for further digital image analysis. Fourteen characters were measured with the aid of WinFolia 4.0 software package (Regent Instruments Inc., Quebec, Canada). These characters represent leaf morphology in size, overall shape and shape of some specific features (lobes, apex, lamina base, etc.) The following characters were measured: petiole length (PL), blade length (BL), maximum blade width (MBW), blade width at $50 \%$ of blade length (BW50), blade width at $90 \%$ of blade length (BW90), apex angle (AA), base angle (BA), angle at $10 \%$ of blade length (A10), angle at $25 \%$ of blade length (A25), blade surface (BS), blade perimeter (BP), number of teeth (NT), ratio between blade length and petiole length (BL_PL) and ratio between blade length and maximum blade width (BL_MBW). Figure 1 describes the fourteen characters that were measured.

Maximum blade width (MBW), petiole length (PL) and blade length (BL) were not considered in the statistical analysis because they showed high correlations with at least one of the other eleven characters (data not shown). A Principal Component Analysis (PCA) with a Varimax Normalized procedure was used to detect those characters contributing most significantly to the variation, and to select a maximum of four characters from those with the highest weights in each factor, thus simplifying further analysis. An ANOVA was performed on 


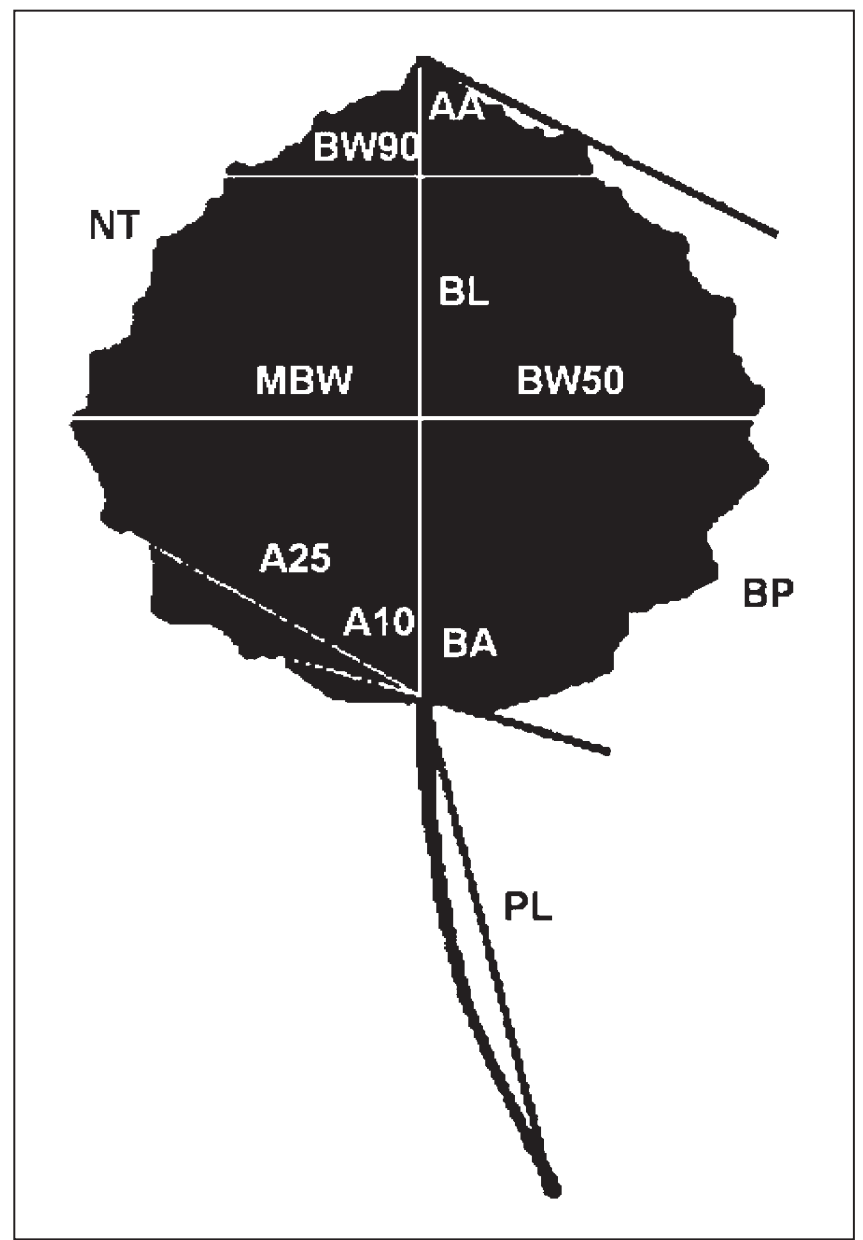

Figure 1. - Characters measured in leaves: petiole length (PL), blade length (BL), maximum blade width (MBW), blade width at the $50 \%$ of the blade length (BW50), blade width at the $90 \%$ of the blade length (BW90), apex angle (AA), basis angle (BA), angle at the $10 \%$ of the blade length (A10), angle at the $25 \%$ of the blade length (A25), blade surface (BS), blade perimeter (BP), number of teeth (NT), ratio between blade length and petiole length (BL_PL) and ratio between blade length and maximum blade width(BL_MBW).

each of the four selected characters to check the percentage of variance due to within population variation. All the analyses were performed with Statistica 5.5 (PCA) and SAS 6.3 for Windows (ANOVA).

\section{Comparison between morphological and genotype data}

In order to check at what extent morphological markers are conditioned by the genotypes or clones, hierarchical ANOVA were performed in 13 of the 14 measured traits (apex angle was discarded) with the following model: $Y_{\mathrm{ijk}}=\mu+\alpha_{\mathrm{i}}+\beta_{\mathrm{ji})}+$ $\varepsilon_{i j \mathrm{k}}$, where $\mu$ is the mean of the morphological trait, $\alpha_{i}$ the effect of the genotype $i, \beta_{\mathrm{j}(\mathrm{i})}$ the effect of the tree $j$ within the genotype $i$ and $\varepsilon_{\mathrm{ijk}}$ the error in the leaf $k$ of the tree $j$ in the genotype $i$. All the factors are independent and show a normal distribution as follows: $\alpha_{\mathrm{i}}: \mathrm{N}\left(0, \sigma_{\mathrm{G}}\right) ; \beta_{\mathrm{j}(\mathrm{i})}: \mathrm{N}\left(0, \sigma_{\mathrm{T}}\right) ; \varepsilon_{\mathrm{ijk}}: \mathrm{N}(0, \sigma)$. Estimators of $\mu, \sigma_{\mathrm{G}}, \sigma_{\mathrm{T}}$ and $\sigma$ were obtained by maximum likelihood. As these estimators are asymptotically normal, we built the following hypothesis tests for the three variance components:

$$
\begin{aligned}
& \mathrm{H}_{0}: \sigma_{G}^{2}=0 \backslash \mathrm{H}_{1}: \sigma_{G}^{2}>0 \\
& \mathrm{H}_{0}: \sigma_{T}^{2}=0 \backslash \backslash \mathrm{H}_{1}: \sigma_{T}^{2}>0 \\
& \mathrm{H}_{0}: \sigma^{2}=0 \backslash \mathrm{H}_{1}: \sigma^{2}>0
\end{aligned}
$$

The variance-covariance matrixes of the estimators $\hat{\sigma}_{\mathrm{G}}^{2}, \hat{\sigma}_{\mathrm{T}}^{2}$ and $\hat{\sigma}^{2}$ were calculated and three aditional tests were run:

$$
\begin{aligned}
& \mathrm{H}_{0}: \sigma_{G}^{2}-\sigma_{T}^{2}=0 \quad \| \mathrm{H}_{1}: \sigma_{G}^{2}-\sigma_{T}^{2}>0 \\
& \mathrm{H}_{0}: \sigma_{G}^{2}-\sigma^{2}=0 \quad \| \mathrm{H}_{1}: \sigma_{G}^{2}-\sigma^{2}>0 \\
& \mathrm{H}_{0}: \sigma_{G}^{2}-\sigma_{T}^{2}-\sigma^{2}=0 \quad \| \mathrm{H}_{1}: \sigma_{G}^{2}-\sigma_{T}^{2}-\sigma^{2}>0
\end{aligned}
$$

These tests were contrasted to check the amount of variance due to each factor and if there is any influence of the genotype in the morphological traits.

\section{Results}

Isozyme analysis

Figure 2 shows the banding patterns of seven enzyme systems (IDH, 6PGD, GOT, LAP, ADH, SKDH and PGI,) and the interpretation given. The PGM and ACPH enzyme systems were discarded because they did not show reproducible banding patterns. In $\mathrm{MDH}$, five patterns were obtained, but no interpretation was possible. Interpretation of $\mathrm{MDH}$ system is not always easy in forest species due to several coding loci and the presence of hybrid bands (THORMANN and StEPHAN, 1993).

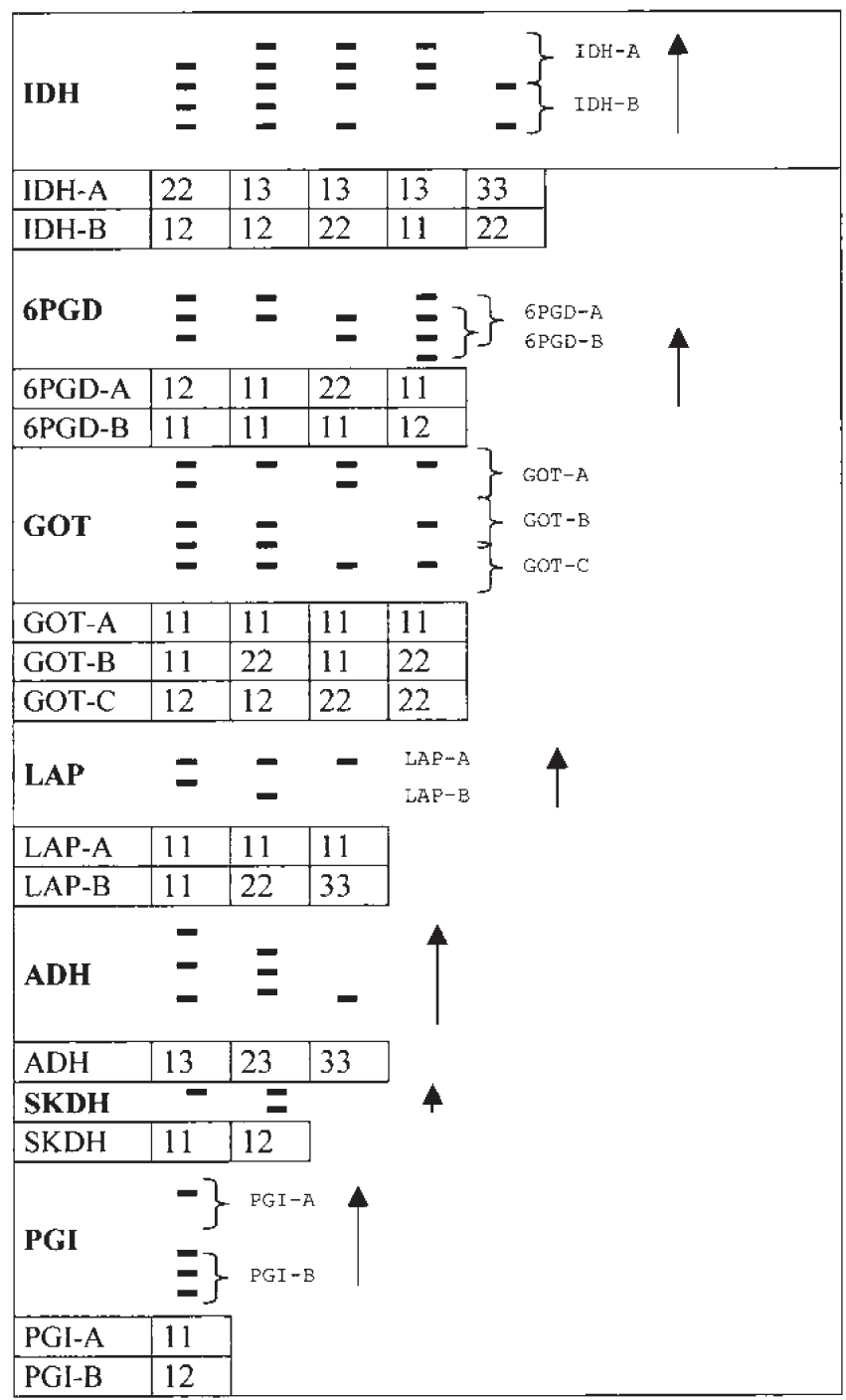

Figure 2. - Interpretation of the banding patterns in seven enzyme systems: IDH, 6PGD, GOT, LAP, ADH, SKDH and PGI. Capital letters stand for loci and numbers for alleles. 
Table 3. - Diversity parameters in each population: Mean number of alleles $(\mathrm{Na})$, Effective number of alleles $(\mathrm{Ne}), \%$ of polymorphic loci $(\mathrm{P})$, Observed (Ho) and expected Nei's heterozygosity (He), Total number of multilocus genotypes (NG), Relative number of multilocus genotypes $\left(\mathrm{NG}_{\mathrm{r}}\right)$ and mean heterozygosity. Overall values are computed as if all the individuals would belong to a single population.

\begin{tabular}{ccccccc} 
& VEL & VALC & TRE & SAL & CON & Overall \\
\hline $\mathbf{N a}$ & 1.69 & 1.85 & 1.61 & 1.69 & 1.69 & 2.00 \\
$\mathbf{N e}$ & 1.54 & 1.61 & 1.27 & 1.50 & 1.37 & 1.59 \\
$\mathbf{P}$ & 61.54 & 69.23 & 53.85 & 61.54 & 69.23 & 76.92 \\
$\mathbf{H}_{\mathbf{o}}$ & 0.37 & 0.37 & 0.25 & 0.37 & 0.31 & 0.33 \\
$\mathbf{H}_{\mathbf{E}}$ & 0.26 & 0.31 & 0.15 & 0.26 & 0.21 & 0.31 \\
$\mathbf{N G}$ & 9 & 12 & 7 & 7 & 6 & 41 \\
$\mathbf{N G}_{\mathbf{r}}$ & 0.36 & 0.41 & 0.23 & 0.30 & 0.21 & 0.30 \\
\hline \multicolumn{7}{c}{ Mean Heterozygosity } \\
\hline
\end{tabular}

\section{Lopez-De-Heredia et al. Silvae Genetica (2004) 53-5/6, 227-233}

Support for the following interpretations can be found in previous research on Populus species (GALlo and GEBUREK, 1991; AlbA and Agúndez, 2000). The PGI system was revealed as monomorphic for the studied populations, hence it was not been considered for the multilocus genotypes. Conversely, the PGI system was taken into account for the rest of genetic parameters.

Table 3 shows diversity parameters for each population mean number of alleles $\left(\mathrm{N}_{\mathrm{a}}\right)$, effective number of alleles $\left(\mathrm{N}_{\mathrm{e}}\right)$, percentage of polymorphic loci, observed $\left(\mathrm{H}_{\mathrm{o}}\right)$ and expected heterozygosity $\left(\mathrm{H}_{\mathrm{e}}\right)$ (NEI, 1973), total number of multilocus genotypes (NG) and relative number of multilocus genotypes

Table 4. - Absolute frequencies of the multilocus genotypes in each population. *indicates the genotypes analyzed morphologically in at least one individual.

\begin{tabular}{|c|c|c|c|c|c|c|c|c|c|c|c|}
\hline Pop & Gtype & IDH-A & IDH-B & 6PGD-A & 6PGD-B & GOT-B & GOT-C & LAP-B & ADH & SKDH & Freq \\
\hline \multirow{9}{*}{ VEL } & 1 & 13 & 12 & 11 & 11 & 11 & 22 & 11 & 13 & 12 & $7^{*}$ \\
\hline & 2 & 13 & 12 & 11 & 11 & 11 & 22 & 11 & 13 & 11 & $1^{*}$ \\
\hline & 3 & 13 & 12 & 11 & 11 & 11 & 12 & 33 & 13 & 12 & $1^{*}$ \\
\hline & 4 & 22 & 12 & 11 & 11 & 11 & 12 & 33 & 13 & 12 & $2^{*}$ \\
\hline & 5 & 22 & 12 & 11 & 11 & 11 & 22 & 33 & 13 & 12 & $8^{*}$ \\
\hline & 6 & 22 & 12 & 12 & 11 & 11 & 22 & 33 & 13 & 12 & 2 \\
\hline & 7 & 22 & 12 & 11 & 11 & 11 & 22 & 11 & 13 & 12 & 1 \\
\hline & 8 & 13 & 12 & 12 & 11 & 11 & 22 & 11 & 13 & 12 & $2 *$ \\
\hline & 9 & 13 & 12 & 12 & 11 & 11 & 12 & 11 & 13 & 12 & $1^{*}$ \\
\hline \multirow{12}{*}{ VALC } & 10 & 13 & 22 & 12 & 11 & 22 & 12 & 11 & 13 & 11 & $3 *$ \\
\hline & 11 & 13 & 22 & 12 & 11 & 22 & 12 & 11 & 23 & 11 & $1 *$ \\
\hline & 12 & 13 & 11 & 12 & 11 & 22 & 12 & 11 & 13 & 11 & $4^{*}$ \\
\hline & 13 & 13 & 22 & 12 & 11 & 22 & 12 & 11 & 13 & 12 & $1^{*}$ \\
\hline & 14 & 13 & 11 & 12 & 11 & 22 & 12 & 11 & 13 & 12 & $5^{*}$ \\
\hline & 15 & 13 & 12 & 22 & 11 & 11 & 22 & 11 & 33 & 11 & $1^{*}$ \\
\hline & 16 & 13 & 12 & 22 & 11 & 11 & 22 & 11 & 23 & 11 & $3^{*}$ \\
\hline & 17 & 13 & 12 & 22 & 11 & 11 & 22 & 22 & 23 & 11 & $1^{*}$ \\
\hline & 18 & 13 & 12 & 12 & 11 & 11 & 22 & 22 & 23 & 11 & 4 \\
\hline & 19 & 13 & 12 & 22 & 11 & 11 & 22 & 22 & 33 & 11 & 2 \\
\hline & 20 & 13 & 12 & 12 & 11 & 11 & 22 & 11 & 23 & 11 & 3 \\
\hline & 21 & 13 & 12 & 12 & 11 & 11 & 22 & 33 & 23 & 11 & 1 \\
\hline \multirow{7}{*}{ TRE } & 22 & 13 & 11 & 11 & 11 & 11 & 22 & 33 & 13 & 11 & 1 \\
\hline & 23 & 13 & 11 & 11 & 11 & 11 & 22 & 33 & 23 & 11 & 5 \\
\hline & 24 & 13 & 11 & 11 & 12 & 11 & 22 & 33 & 23 & 11 & $13^{*}$ \\
\hline & 25 & 13 & 11 & 11 & 12 & 11 & 22 & 33 & 33 & 11 & $3^{*}$ \\
\hline & 26 & 13 & 11 & 11 & 11 & 11 & 22 & 33 & 33 & 11 & $6^{*}$ \\
\hline & 27 & 13 & 11 & 12 & 11 & 11 & 22 & 33 & 33 & 11 & 1 \\
\hline & 28 & 13 & 11 & 11 & 11 & 22 & 12 & 33 & 33 & 11 & $1^{*}$ \\
\hline \multirow{7}{*}{ SAL } & 29 & 13 & 12 & 11 & 11 & 22 & 12 & 33 & 13 & 11 & $9^{*}$ \\
\hline & 30 & 13 & 12 & 11 & 11 & 22 & 12 & 33 & 23 & 11 & $8^{*}$ \\
\hline & 31 & 13 & 12 & 22 & 11 & 22 & 12 & 22 & 13 & 11 & $1^{*}$ \\
\hline & 32 & 13 & 12 & 11 & 11 & 11 & 12 & 22 & 13 & 11 & 1 \\
\hline & 33 & 33 & 22 & 12 & 11 & 22 & 12 & 33 & 13 & 11 & $1^{*}$ \\
\hline & 34 & 33 & 22 & 12 & 11 & 11 & 12 & 33 & 13 & 11 & 2 \\
\hline & 35 & 33 & 22 & 12 & 11 & 11 & 12 & 22 & 13 & 11 & 1 \\
\hline \multirow{6}{*}{ CON } & 36 & 13 & 22 & 12 & 11 & 11 & 12 & 33 & 33 & 11 & $23 *$ \\
\hline & 37 & 13 & 22 & 11 & 11 & 11 & 22 & 33 & 33 & 12 & $1^{*}$ \\
\hline & 38 & 13 & 12 & 11 & 11 & 22 & 22 & 33 & 33 & 12 & 2 \\
\hline & 39 & 13 & 12 & 22 & 11 & 11 & 22 & 33 & 23 & 12 & 1 \\
\hline & 40 & 13 & 11 & 12 & 11 & 22 & 22 & 11 & 23 & 12 & 1 \\
\hline & 41 & 13 & 22 & 12 & 11 & 11 & 12 & 11 & 23 & 11 & 1 \\
\hline
\end{tabular}


$\left(\mathrm{NG}_{\mathrm{r}}=\mathrm{NG} / \mathrm{Nindiv}\right.$ per population)-. Overall values were computed regarding the five populations as if they were a single one (YeH et al., 1999). Overall number of alleles per locus was 2.00, ranging from 1.61 in Tremaya to 1.85 in Valcobero. The percentages of polymorphic loci ranged from 53.85 (Tremaya) to 69.23 (Valcobero and Congosto), with an overall value of 76.92. The observed heterozygosity was higher than expected, ranging from 0.25 (Tremaya) to 0.37 (Valcobero), with an overall value of 0.33 . The number of multilocus genotypes varied from 6 in Congosto to 12 in Valcobero. In the 136 individuals analyzed, 41 different multilocus genotypes were found (9 in Velilla, 12 in Valcobero, 7 in Tremaya, 7 in Salcedillo and 6 in Congosto being the total number of samples in each population $25,29,30,23$ and 29 respectively). Thus, overall diversity parameters were higher than those ones per population, indicating an isolation of the stands. Moreover, no equal genotypes were found in individuals from different populations.

Table 4 shows the frequencies of the different genotypes found in each population. The results agree with the different structures of the populations. Large, young and vigorous populations showed a higher number of genotypes with more balanced frequencies of genotypes than populations in mature stages. Valcobero and Velilla showed the highest number of different genotypes (12 genotypes in 29 samples and 9 in 25 , respectively) and frequencies of the genotypes were quite balanced. In Salcedillo (7 out of 23) and Congosto (6 out of 29) fewer different genotypes were recorded than in the younger, more vigorous stands, and most of the individuals present the same genotypes. Tremaya ( 7 out of 30 ), showed a small number of different genotypes and its distribution of frequencies was similar to that of Congosto and Salcedillo. Nevertheless, Tremaya presents a different structure quite unlike that of Salcedillo and Congosto. The number of young individuals is significant and may have been developed by root suckers from a pre-existing stand dominated by oak and beech.

\section{Morphological Analysis}

The PCA showed that five factors accounted for $92 \%$ of variance (Table 5). Four variables were selected among those with higher weights in each factor: base angle (BA), blade perimeter (BP), number of teeth (NT) and the relationship between blade length and petiole length (BL_PL). Apex angle (AA) was eliminated because it reflects the angle of the upper teeth rather than the shape of the apex. Each of the factors relates to one aspect of leaf morphology. Base angle (BA) reflects the shape of the base of the blade at the insertion point with the petiole, blade perimeter (BP) is indicative of leaf size, the number of teeth (NT) indicates regularity of the blade and the relationship between blade length and petiole length (BL_PL) is a measure of the overall shape of the leaf. These characters are shown in Table 5, with their percentage of explained variance. A PCA plot (Figure 3) with the two characters with the higher

Table 5. - Results of the PCA. Total and accumulated percentages of variance explained, characters with the highest weights (height $>0.700$ ) in each factor and morphological characteristic defined by each factor. In bold, the four characters selected for further analysis. A10: angle at the $10 \%$ of the blade length, A25: angle at the $25 \%$ of the blade length, BA: basis angle, BW50: blade width at the $50 \%$ of the blade length, BS: blade surface, BP: blade perimeter, AA: apex angle, BL_PL: ratio between blade length and petiole length, NT: number of teeth.

\begin{tabular}{|c|c|c|c|c|c|}
\hline & \multicolumn{5}{|c|}{ Factors } \\
\hline & 1 & 2 & 3 & 4 & 5 \\
\hline \multirow{3}{*}{$\begin{array}{l}\text { Characters with } \\
\text { highest weights }\end{array}$} & A10 & BW50 & & & \\
\hline & A25 & BS & AA & BL $\mathbf{P L}$ & NT \\
\hline & BA & BP & & & \\
\hline \multirow{2}{*}{$\begin{array}{l}\% \text { of total variance } \\
\text { Accumulate \% of } \\
\text { variance }\end{array}$} & 47.89 & 20.81 & 9.71 & 8.91 & 4.73 \\
\hline & 47.89 & 68.70 & 78.42 & 87.32 & 92.05 \\
\hline
\end{tabular}

weights from the first two factors shows variation both within and between populations. An ANOVA also shows variation both within and between populations in the four selected traits. Therefore, three shape and one size parameters are enough to detect inter- and intrapopulational variation.

\section{Comparison between morphological and genotype data}

For all the morphological traits, the tests of hypothesis (1), (2) and (3) were significant $(p<0.05)$. As shown in Figure 4 , for all the morphological traits (except blade perimeter (BP), blade length (BL), petiole length (PL) and blade width at $90 \%$ of blade length (BW90)) the estimated component of the genotype exceeds $50 \%$ of the total variance. That is, for size related traits the genotype influence is less than for shape related traits. Hypothesis 4 was significant for all the morphological traits, except for the blade length $(\mathrm{BL})(\mathrm{p}=0.083)$ and for the petiole length $(\mathrm{PL})(\mathrm{p}=0.054)$. Therefore, the 'genotype' component is significantly higher than the 'tree' component of variance (except for BL and PL).

Hypothesis 5 is significant for base angle (BA) $(p=0.003)$, angle at $10 \%$ of blade length (A10) $(p=0.006)$, angle at $25 \%$ of blade length (A25) $(p=0.006)$ and ratio between blade length and maximum blade width $\left(\mathrm{BL} \_\mathrm{MBW}\right)(\mathrm{p}=0.044)$. For the number of teeth (NT) the p-value is very close to significance $(p=0.053)$. All of these traits are related to the shape of the leaf, and they show a significantly higher 'genotype' component than the stochastic component of variance.

Finally, hypothesis 6 is significant for base angle (BA) $(\mathrm{p}=0.007)$, at $10 \%$ of blade length (A10) $(\mathrm{p}=0.011)$, angle at $25 \%$ of blade length (A25) $(\mathrm{p}=0.010)$. Therefore, we can say that morphological traits related to leaf shape show a remarkable component of variance due to genotype ( $>75 \%$ of the total variance, Figure 4), and hence, the clonal component in the shape of the leaf traits is very high.

\section{Discussion}

There are two remarkable results in this study. First, regarding the isozyme patterns of the individuals, we can see that within population diversity is higher than expected. HAMRICK et al. (1992) established the link between high diversity levels in natural populations and seed production. European aspen produces large amounts of seeds, although flowering can be irregular from year to year. In areas with wet summers, such as Scotland, heavy flowering seldom occurs (EASTON, 1997; WoRRELL et al., 1999). However, as far as Spain is concerned, flowering seems to occur frequently and seeds can show high rates of germination (SIERRA DE GRADo et al., 2002). This high seed viability results in a large number of different genotypes in the individuals that colonize bare sites. Indeed, our results suggest that the initial number of seedlings in natural populations is higher than has been generally assumed.

On the other hand, the isozyme analysis shows that the same isozyme pattern does not occur in more than one population. Thus, each population has unique isozyme patterns. Regarding the description of the populations, a relationship seems to exist between the stand vitality and the distribution of the multilocus genotypes in the populations. The fact that some individuals with the same isozyme multilocus patterns are predominant may be explained in terms of the natural selection, and this is more obvious in mature stands. In early successional stages, a larger number of genotypes was established, but different selection pressures lead to some of them to become dominant, by asexual propagation in mature stages.

These results do not agree with traditional views on the homogeneous character of aspen stands and, indeed, with their 


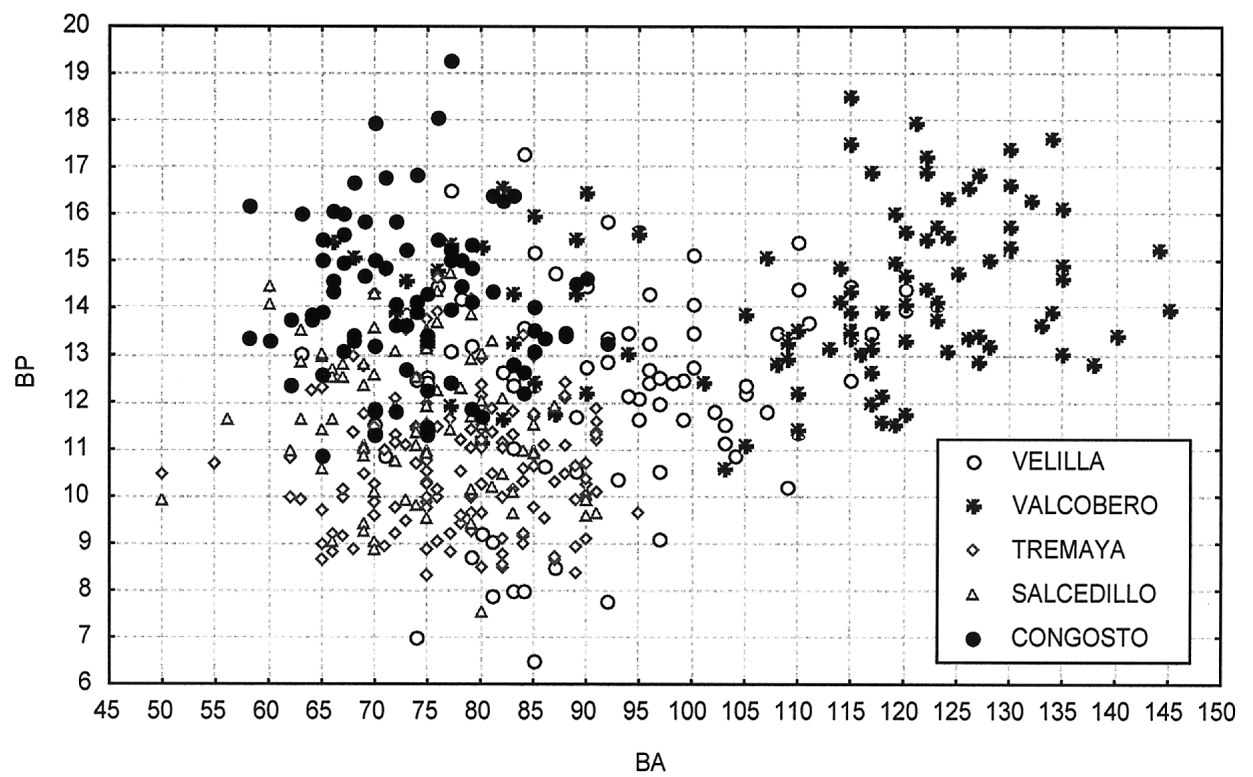

Figure 3. - PCA plot of the two characters with the highest weights from factors 1 and $2 . \mathrm{BP}=\mathrm{Blade}$ Perimeter; $\mathrm{BA}=$ Base Angle.

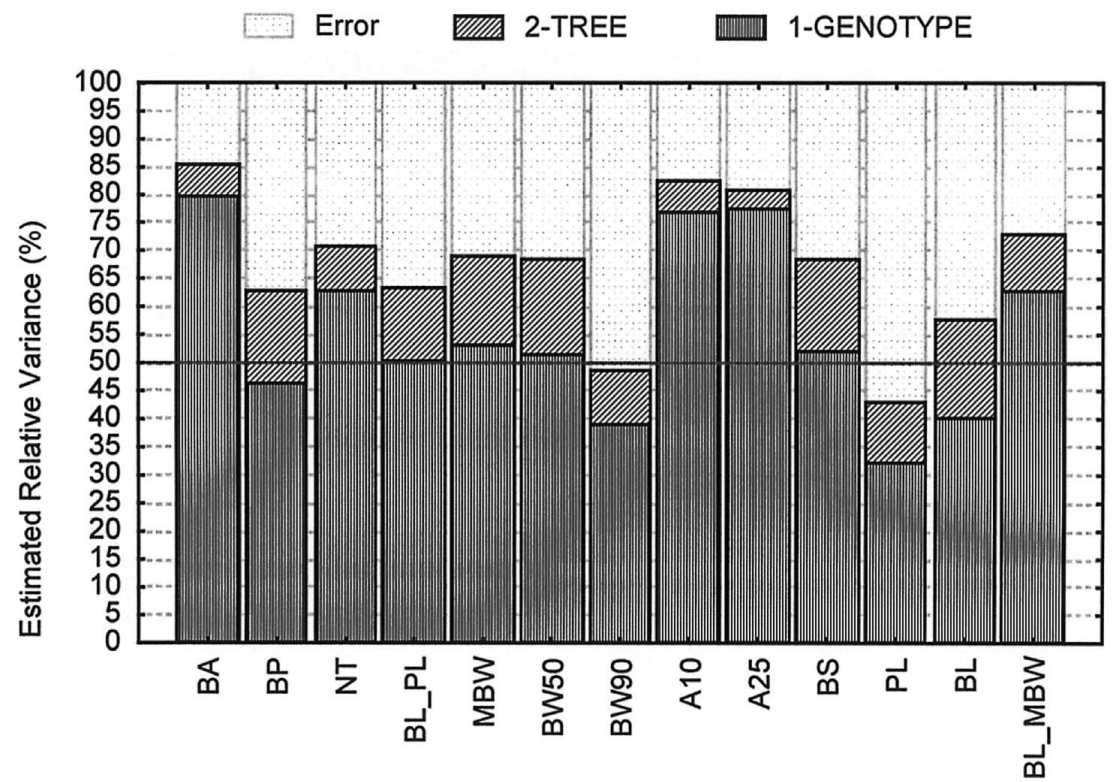

Figure 4. - Plot of the components of variance for the 13 morphological traits analyzed.

monoclonal character (HEYBROEK, 1984; WoRRELL, 1995). Therefore, it can have serious implications in the management of endangered small aspen populations, which are frequently treated as monoclonal stands.

The other remarkable result is that a small number of specific morphological traits are enough to detect variation and adequately define leaf morphology in aspects such as size (BP), ratio of blade length and petiole length (BL_PL), base angle (BA) or number of teeth (NT). As shown by the ANOVA, leaf morphology reveals variation both within and between populations. Since morphological traits are very plastic, any recorded variation should not necessarily be interpreted as genetic variation. Actually, studies comparing isozymes with morphological markers are rare in forest tree species (HAMRICK, 1989; SCHAAL et al., 1991) and in genus Populus in particular (FARMER, 1996).
For our purposes, however, we may assume that a discriminanting power of $89 \%$ for these isozyme loci in Tremaya (report in preparation) is good enough to have an estimation of the individuals that belong to a single genotype, and therefore, we can afford the comparison between isozyme multilocus patterns and morphological traits. Actually, our results show that in European Aspen in marginal populations, leaf morphology is well correlated with the individuals showing the same isozyme multilocus patterns, mainly in the case of parameters related to the shape of the leaf (angles). This is explained if we consider that size of the leaves might be conditioned by environmental factors such as light exposure or water availability, while shape of the leaves would be more stable against environmental changes (KREMER et al., 2002). In this sense, it is noteworthy that the variance component due to genotype is significant- 
ly higher than variance component of tree within genotype plus error in the parameters related to shape. This suggests that even in different microenvironments or with different exposures to light of leaves within a tree, these markers are mostly influenced by the genotype.

That is, even if not tested in a field trial, it seems clear that there is a clonal component for some morphological parameters. Hence, these parameters can be used as cheap diagnostic markers in early identification of clones for further selection or as tools for the definition of in situ conservation units in endangered or marginal populations.

Management plans and conservation programs dealing with natural stands of European aspen must take into account that the intra-population genetic diversity is essential. Failure to do so by uncritically accepting the widespread assumption about a monoclonal nature of these stands could result in an important loss of diversity. Future studies on the clonal distribution of these stands, using both isozyme and morphological markers, will provide new insights into $P$. tremula clonal strategies and stand dynamics for the design of suitable management plans and conservation strategies.

\section{Acknowledgements}

This study was supported by the Consejería de Educación y Cultura of the Junta de Castilla y León, through the project VA 40/99. We thank Dr. R. Alía for his valuable suggestions and for an early review of the paper.

\section{References}

Alba, N. and D. Agúndez (2000): Characterization of Populus alba by isozymes. Investigación Agraria: Serie Forestal 9: 305-311.

Alvarez, M. T., R. Sierra De Grado, P. Martínez Zurimendi and V. PANDo (2001): Propagación de Populus tremula L. a partir de semilla. Actas del I Simposio del Chopo de Castilla y León. Zamora, 9-11 de Mayo de 2001. pp. 273-279.

Aspinwall, N. and T. CHRistian (1992): Clonal structure, genotypic diversity and seed production in populations of Filipendula rubra (Rosaceae) from the northcentral United States. Am. J. Botany 79(3): 294-299.

BARNeS, B.V. (1969): Natural variation and delineation of clones of Populus tremuloides and P. grandidentata in Northern Lower Michigan. Silvae Genetica 18 (4): 130-142.

BARNeS, B.V. and F. HAN (1993): Phenotypic variation of Chinese aspens and their relationships to similar taxa in Europe and North America. Can. J. Bot. 71: 799-815.

Bergmann, F. (1987): Characterization of multiclonal aspen cultivars using enzyme electrophoresis. For. Ecol. and Manage. 22: 167-172.

Culot, A. (1993): Contribution a l'etude des peupliers de la section Leuce. La variation morphogénétique de Populus tremula L., P. alba L., P. canescens (Ait.) Sm. Et leurs hybrides. $\mathrm{PhD}$. Thesis. Universite Libre de Bruxelles. $190 \mathrm{pp}$.

EASTON, E. P. (1997): Genetic variation and conservation of the native aspen (Populus tremula L.) resources in Scotland. $\mathrm{PhD}$. Thesis. The University of Edinburgh. $267 \mathrm{pp}$.

EINSPAHR, D. W. and L. L. WINTON (1976): Genetics of quaking aspen. Res. Pap. WO-25. Washington, DC: U.S. Department of Agriculture, Forest Service. $23 \mathrm{pp}$.

FARMER, R. E. JR. (1996): The genecology of Populus. In: Biology of Populus and its implications for management and conservation. R. F. Stettler, H. D. Bradshaw JR., P. E. HeIlman and T. M. HINCKLEY (eds.). NRC Research Press, National Research Council of Canada, Ottawa, ON, Canada, pp. 33-55.

Gallo, L. A. and Geburek, T. (1991): Genetics of isozyme variants in Populus tremula, Populus tremuloides, and their hybrids. Euphytica 53: 225-233.

HAMRICK, J. L. (1989): Isozymes and the analysis of genetic structure in plant populations. In: Soltis, D. E. and Soltis,
P. S. (eds) Isozymes in Plant Biology. Chapman and Hall, London, pp. 87-105.

Hamrick, J. L., M. J.W. Godt and S. L. Sherman-Broyles (1992): Factors influencing levels of genetic diversity in woody plant species. In: Population genetics of forest trees. Proceedings of the International Symposium of Population Genetics of Forest Trees. Corvallis, Oregon, USA, July 31-August 2, 1990. Kluwer Academic Publishers, Dordrecht, Netherlands, pp. 97-123.

Heybroek, H. M. (1984): Clones in Forestry and in Nature. Arboricultural Journal 8: 275-286.

JELINSKY, D. E. and W. M. CHELIAK (1992): Genetic diversity and spatial subdivision of Populus tremuloides (Salicaceae) in a heterogeneous landscape. Amer. J. Bot. 79 (7): 728-736.

Kremer, A., JL. Dupouey, D. Deans, J. Cottrell, U. Csaikl, R. Finkeldy, S. Espinel, J. Jensen, J. Kleinschmit, B. Van Dam, A. Ducousso, I. Forrest, U. Lopez De Heredia, AJ. Lowe, M. Tutkova, RC. Munro, S. Steinhoff and V. Badeau (2002): Leaf morphological differentiation between Quercus robur and Quercus petraea is stable across western European mixed oak stands. Ann. For. Sci. 59: 777-787.

Lund, S. T., G. R. Furnier and C. A. Mohn (1992): Isozyme variation in quaking aspen in Minnesota. Can. J. For. Res. 22: 521-524.

MadOZ, P. (1845-1850): Diccionario Geográfico Estadístico Histórico. Palencia. Edición facsimil de la Diputación Provincial de Palencia.

Mayes, S. G., M. A. McGinley and C. R. Werth (1998): Clonal population structure and genetic variation in sand-shinnery oak, Quercus havardii (Fagaceae) Am. J. Botany 85(11): $1609-1617$.

Montalvo, A. M., S. G. Conard, M. T. Conkle and P. D. HoDKskiss (1997): Population structure, genetic diversity, and clone formation in Quercus chrysolepis (Fagaceae). Am. J. Botany 84(11): 1553.

NEI, M. (1973): Analysis of genetic diversity in subdivided populations. Proc. Natl. Acad. Sci. USA 70: 3321-3323.

ORIA De RuedA, J. A. (2003): Distribución geográfica del álamo temblón. In: Sierra De Grado (Ed.). El álamo temblón (Populus tremula L.) Bases para su cultivo, gestión y conservación. MundiPrensa Libros SA. Madrid. pp. 71-86.

RAJORA, O. P. and B. P. DANCIK (1992): Genetic characterization and relationships of Populus alba, Populus tremula, and P. $x$ canescens, and their clones. Theor. Appl. Genet. 84: 291-298.

SchaAl, B. A., W. J. Leverich and S. H. Rogstad (1991): A comparison of methods for assessing genetic variation in Plant Conservation Biology. In: FALK, D. A. and Holsinger, K. E. (Eds). Genetics and conservation of rare plants. Oxford University Press pp. 123-134.

SCHIER, G. A. (1973): Seasonal variation in sucker production from excised roots of Populus tremuloides and the role of endogenous auxin. Canadian Journal of Forest Research. 3(3): 459-461.

Sierra De Grado, R., P. Martínez Zurimendi and U. López De HEREDIA (2002): Reproducción sexual y diversidad genética de Populus tremula. In: Sierra De Grado (Coord.) El álamo temblón (Populus tremula L.) Bases para su cultivo, gestión y conservación. MundiPrensa Libros SA Madrid. pp. $151-166$.

Thormann, R. and B. R. Stephan (1993): Interpretation of isozyme patterns of malate dehydrogenase in Scots pine using two different staining methods. Silvae Genetica 42 (1): $5-8$.

WorRell, R. (1995): European Aspen (Populus tremula L.): a review with particular reference to Scotland. I. Distribution, ecology and genetic variation. Forestry $68(2)$ : 93-105.

Worrell, R., A. G. Gordon, R. S. LeE and A. McInroy (1999): Flowering and seed production of a spen in Scotland during a heavy seed year. Forestry 72(1): 27-34.

Yeh, F. C., R. YANG and T. Boyle (1999): Popgene Version 1.31. Microsoft Window-based Freeware for Population Genetic Analysis. Quick User Guide. 